\title{
Cytotoxic Assay of Semipolar Fraction Of Ethanolic Extract From Sugar Apple (Annona Squamosa L.) Stem Bark on T47D Cells
}

\author{
Cita Hanif Muflihah*, Haryoto Haryoto, Peni Indrayudha \\ Fakultas Farmasi Universitas Muhammadiyah Surakarta, J1. A. Yani Tromol Pos I, Pabelan Kartasura Surakarta \\ 57102 \\ *Email: cita.h.muflihah@ums.ac.id
}

Received: 8 October 2020; Accepted: 28 December 2020; Published: 31 December 2020

\begin{abstract}
Previous research has shown that some compounds in leaves and seeds of sugar apple have a cytotoxic activity. The aim of this research was to determine the cytotoxicity of semipolar fraction of ethanolic extract from sugar apple stem bark (Annona squamosa L.) on T47D cancer cells. The semipolar fraction of ethanolic extract from sugar apple stem bark was collected by fractionation using Vacuum Liquid Chromatography (VLC) with hexane:ethyl acetic (9:1, 8:2, 7:3, and 6:4) as mobile phase. Cytotoxicity from the fractions of five different concentration namely; $25,50,100,150$, and $250, \mu \mathrm{g} / \mathrm{mL}$ was measured by MTT assay. The potency of the cytotoxicity was defined by the ability of the fraction to inhibit the growth of T47D cells indicated by the value of $\mathrm{IC}_{50}$. Qualitative analysis of contained compounds in the fraction was done by Thin Layer Chromatography (TLC) method using silica gel F 254 as a stationary phase and hexane:ethyl acetic (7:3) as a mobile phase. UV 254 and $366 \mathrm{~nm}$ lamp also Dragendorff, citroboric, and $\mathrm{FeCl}_{3}$ spray reagents were used to visualize the spots of the secondary metabolites. The result proved that the semipolar fraction of ethanolic extract from sugar apple stem bark showed potential cytotoxicity on T47D cancer cells with $\mathrm{IC}_{50}$ value of $70,77 \mu \mathrm{g} / \mathrm{mL}$. Qualitative analysis showed that the fraction contained flavonoids and alkaloids which is presumably responsible for its cytotoxic activity.
\end{abstract}

Keywords: Cytotoxic assay, sugar apple (Annona squamosa L.), T47D cells, semipolar fraction.

\section{INTRODUCTION}

The prevalence of cancer in Indonesia ranks at the top ten, reigning as the eight in Southeast Asia. It increased from 1,4 per 1000 in 2013 to 1,79 per 1000 citizens in 2018, with 42,1 per 100.000 cases was caused by breast cancer that contributes to the 17 in 100.000 of deaths in woman (Kementrian Kesehatan RI, 2019). The main goal for cancer therapy is to eradicate the cancerous cells by means of killing the cells or removing the cells (Sullivan et al., 2015). This can be achieved by surgery, radiation, chemotherapy, or immunotherapy. However, it is well known that these methods are expensive, and more likely accompanied by aggravating side effects (Kementrian Kesehatan RI, 2018). Our nature contains abundant sources of compounds that have numerous pharmacological activities. Traditional medicine practice has proved that the empirical use of natural source to fight against diseases is comparatively has lesser side effects than modern medicines (Karimi, Majlesi and Rafieian-Kopaei, 2015). Therefore, the exploration of other potential natural sources is important in order to search for another options for cancer therapy that have relatively less detrimental effects to the patients. One of the potential natural sources is sugar apple (Annona squmosa L.).

Various parts of sugar apple plant have previously been investigated for their pharmacological effects, especially in their cytotoxic activity. The methanol extract of sugar apple's leaves and seeds were reported to have $\mathrm{LC}_{50}$ value of $0.63 \mu \mathrm{g} / \mathrm{mL}$ and 0.10 $\mu \mathrm{g} / \mathrm{mL}$ respectively, in Brine Shrimp lethality Test (Pisutthanan et al. 2004). Other report showed that the organic and water extracts of sugar apple's seeds could induce the apoptosis of MCF-7 and K-562 cells (Pardhasaradhi et al., 2005). In another research it is proved that the crude extract and the ethyl acetate extract of sugar apple leaves possessed cytotoxicity against human 
epidermoid carcinoma cell line KB-3-1 and colon cancer cell line HCT-116 (Wang et al., 2014)

Based on the previous findings, it could be concluded that the parts of sugar apple plant have diverse advantages, thus, this research was aimed to evaluate the cytotoxicity of semipolar fraction of ethanol extract from sugar apple's stem bark against T47D cells. We also performed a qualitative test of the fraction in order to predict the secondary metabolites content responsible for its activity using TLC method.

\section{MATERIALS AND METHODS Materials}

The verification of the plant was performed in the Biology Pharmacy Laboratory of Universitas Muhammadiyah Surakarta. The stem bark of sugar apple was collected directly from the local neighborhood plant, dried, and powdered. Various organic solvents were used for extraction such as hexane, ethyl acetate, and ethanol. Dragendorff, sitroboric, and $\mathrm{FeCl}_{3}$ reagents were used to visualize alkaloids, flavonoids, and phenolic compounds. T47D cell line was obtained from CCRC UGM. RPMI media, PBS (phosphate buffer saline), trypsin-EDTA, DMSO (dimethyl sulphoxide), and MTT reagent were used during cytotoxic assay.

\section{Extraction and fractionation}

Extraction was performed on powdered samples by maceration using $96 \%$ ethanol (ratio 1:7.5) for 24 hours in a dark, closed container followed by filtration. The filtrate was concentrated using rotary evaporator and waterbath. The ethanol extract was then fractioned using VLC method. $25 \mathrm{~g}$ extracts were impregnated with silica G60 (30-70 mesh) weigh twice as much as the extract. This mixture was then placed on top of the dense and compact $14 \mathrm{~cm}$ column of silica gel GF254. Fractionation was performed in triplicates. Elution was performed fourteen times for every replication, each time using $150 \mathrm{~mL}$ solvent with escalated polarity system as follows; three times of hexane: ethyl acetate $(9: 1)$; four times of hexane:ethyl acetate (8:2); four times of hexane: ethyl acetate (7:3); three times of hexane: ethyl acetate (6:4); and twice of $96 \%$ ethanol. 50 $\mathrm{mL}$ of each fraction was collected and each sample was spotted onto a TLC silica plate and developed. This step was done in order to classify all of the fractions into three different categories of nonpolar, semipolar, and polar fractions respectively. Three fractions were then evaporated until thick consistency was obtained. In this experiment, we focused on evaluating the semipolar fraction of the extract.

\section{Qualitative analysis using TLC}

Secondary metabolites content in the semipolar fraction was identified using TLC method. The stationary phase used was silica GF254 while the solvent system was hexane:ethyl acetate (7:3). The spots were visualized under UV 254 and $366 \mathrm{~nm}$ light prior as well as after sprayed with reagents such as Dragendorff, sitroboric, and FeCl3.

\section{T47D culture media}

T47D cells were cultured in RPMI 1640 media. The media was made by mixing RPMI powder, hepes buffer, and sodium bicarbonate buffer of $\mathrm{pH}$ 7.4. Complete media was obtained after adding $10 \%$ of FBS (fetal bovine serum), $2 \%$ of penicillinstreptomycin, and $0.5 \%$ of fungizone.

\section{MTT cytotoxic assay}

After T47D cells achieved $80 \%$ of confluence, the cells were detached using trypsin-EDTA. The cells were then washed, and counted using hemacytometer. The cells were then plated into a 96-well plate with $10^{4}$ cells for each well. The fraction was diluted in DMSO into five different concentrations of $25,50,100,150$, and $250, \mu \mathrm{g} / \mathrm{mL}$ and then $100 \mu \mathrm{L}$ of each concentration was added into the wells. The plate was then incubated for 24 hours. The following day, the cells were washed with PBS and $100 \mu \mathrm{L}$ of the MTT (3(4,5-dimethylthiazole-2il)-2,5-

diphenyltetrazoliumbromide) in media solution was added into the wells. MTT is the 


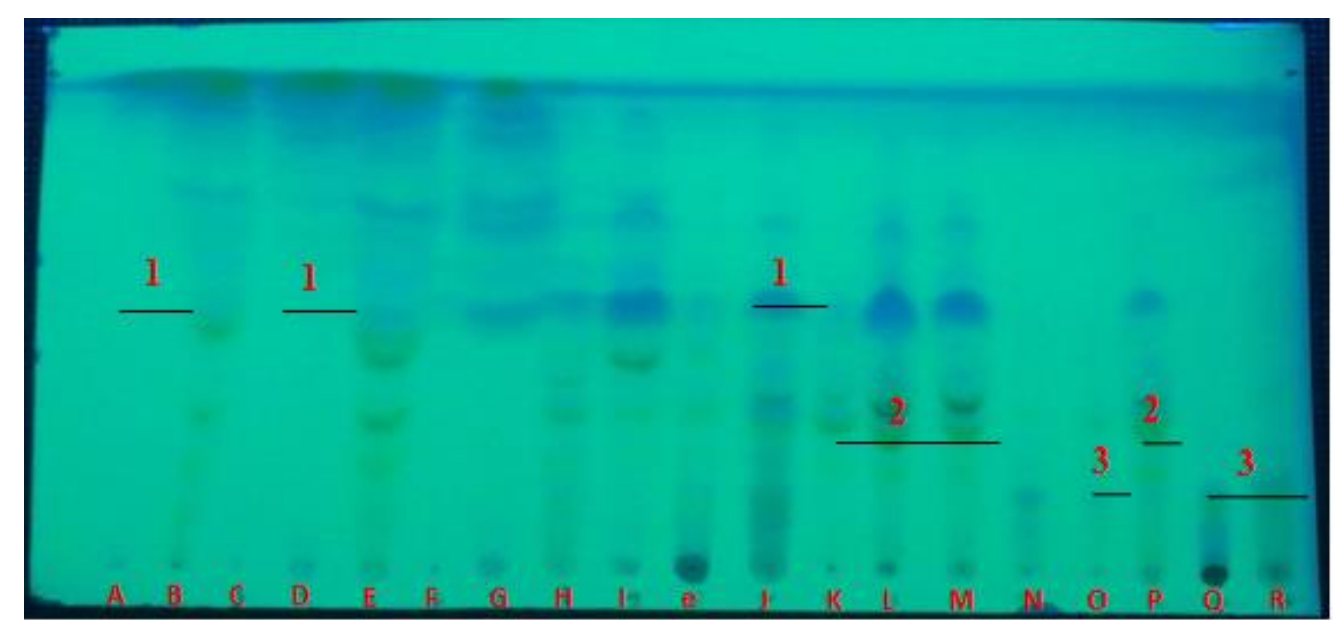

Figure 1. Chromatogram from TLC of eighteen fractions were classified into three groups. (1) Nonpolar fraction, (2) semipolar fraction, and (3) polar fraction.

substrate for metabolic enzymes of the cells. MTT would be reduced into purple formazan crystals by the living cells, indicating that the growth was not inhibited by the presence of the fractions. Next, the plate was then incubated again for another four hours. The reduction of tetrazolium salts into formazan by the survived cells was happened in this period. In order to stop the reaction as well as to dilute the formazan crystals formed, $10 \%$ of SDS (sodium dodecyl sulphate) in HCL solution was added. Subsequently, the plate was incubated in the closed dark room temperature place overnight. The next day, the absorbance of the solution from each well was measured in $550 \mathrm{~nm}$. The data obtained was used to calculate the percentage of the survived cells using following equation;

Surviving cells $(\%)=$

$\frac{\text { (abs. treated groups }- \text { abs. background) }}{(\text { abs. control of living cells }- \text { abs. background })} \times 100 \%$

with abs. background means the absorbance of the control media as the background. Then, IC50 value was extrapolated from the linear regression equation obtained by the correlation between log of the concentration of the fractions and the percentage of survived cells. $X$ value represented the $\log$ of the concentration, while Y value represented 50\% inhibition of the cell growth.

\section{RESULTS AND DISCUSSION \\ Extraction and fractionation}

Extraction with $96 \%$ ethanol by maceration resulted in $12.34 \%$ yield, as much as $295.55 \mathrm{~g}$ concentrated extract of sugar apple's stem bark was obtained at the end of the extraction process. Following the fractionation step, in total, fourteen fractions from the mixture of hexane:ethyl acetate solvent and two fractions of $96 \%$ ethanol were collected. Preliminary TLC was performed in order to categorize the polarity of the fractions obtained. The spots were observed under the UV light. The result showed that there were in total of eighteen fractions (A-R) obtained (Figure 1). Eighteen fractions were subsequently spotted onto silica GF254 and developed with hexane:ethyl acetate (8:2). This step was done in order to classify them into three groups of nonpolar, semipolar, and polar fractions based on their chromatogram patterns. As we used hexane:ethyl acetate (8:2) for a mobile phase and silica GF254 as a stationary phase, it is clear that this was a normal phase for a TLC method where the solvent is less polar than the plate. Thus, with "like dissolve like" principle, all the nonpolar compounds would be at the end point of the 
Table 1. Concentrations of the fraction used during MT assay and their abilities to inhibit T47D cells proliferation indicating by the percentage of surviving cells after the treatments

\begin{tabular}{ccc}
\hline $\begin{array}{c}\text { Concentration } \\
(\boldsymbol{\mu g} / \mathbf{m L})\end{array}$ & Log concentration & \% of surviving cells \\
\hline 25 & 1.398 & 96.301 \\
50 & 1.699 & 74.463 \\
100 & 2.000 & 37.828 \\
150 & 2.176 & 4.893 \\
250 & 2.398 & 0.636 \\
\hline
\end{tabular}

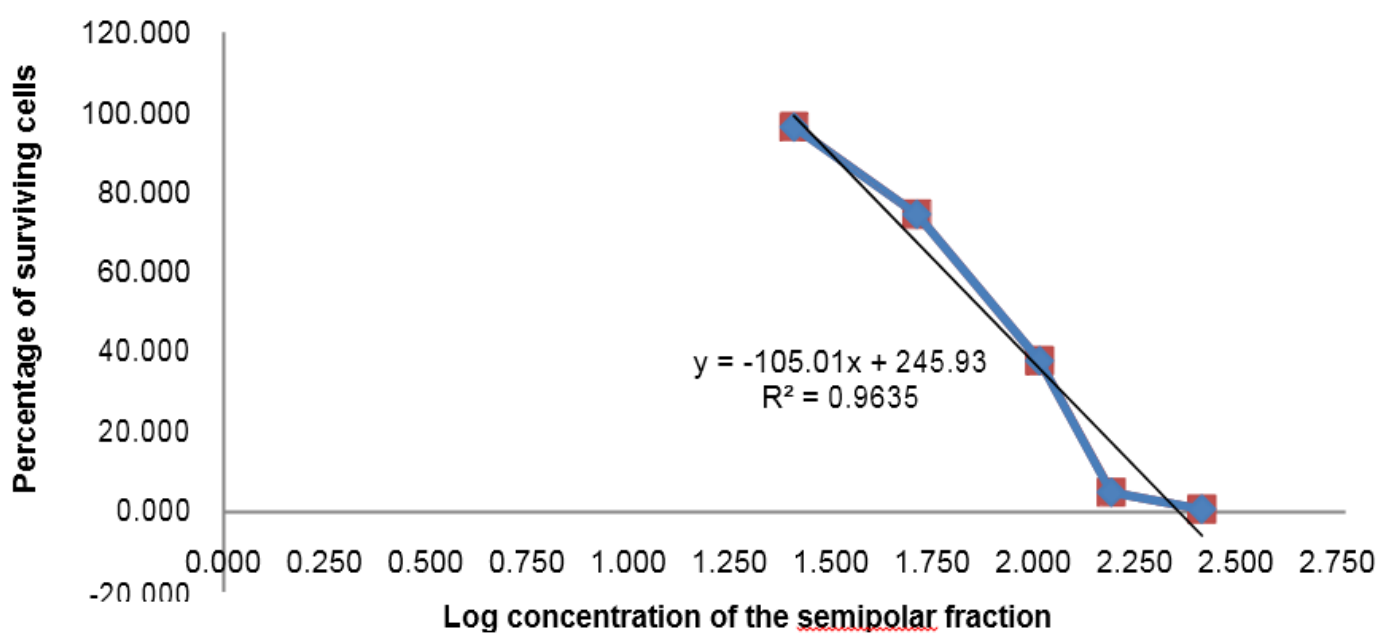

Figure 2. Graphic shows the linear correlation between the percentage of surviving cells and the log of concentrations of the fraction $(R=0.963)$.

elution, while semipolar compounds were in the middle and the polar compounds would be retained near the starting marks of the first spots (Figure 1, indicated with number 1, 2, and 3 respectively). Three fractions obtained were then evaporated and concentrated. By at the end of this step, 4.6 gram of the semipolar fraction with the yield of $1.56 \%$ was achieved MTT cytotoxic assay of the semipolar fraction against $\mathrm{T} 47 \mathrm{D}$ cells

The highest concentration of $250 \mu \mathrm{g} / \mathrm{mL}$ exhibited the most potent cytotoxic activity causing almost $99.32 \%$ of cell death, while the lowest concentration of $25 \mu \mathrm{g} / \mathrm{mL}$ could only cause death on $3.64 \%$ of T47D cells population. The percentage of surviving cells receiving treatments of the fraction in every concentration can be seen in Table 1 .
The cytotoxic potency of the semipolar fraction of the ethanol extract from sugar apple's stem bark against T47D cells is illustrated in Figure 2. The ability of the fraction in killing the T47D cells is indicated by the decrease of the percentage of the surviving cells along with the increase of the fraction's concentration. From the abovementioned graph (Figure 2), the $\mathrm{IC}_{50}$ was then calculated by substituting the $\mathrm{Y}$ value with 50 in the equation. The IC50 value obtained of the semipolar fraction of the ethanol extract from sugar apple's stem bark against T47D cells was $70.77 \mu \mathrm{g} / \mathrm{mL}$. According to Rajabalian (2007), an extract is considered to have weak cytotoxicity if its $\mathrm{IC}_{50}$ value turns to be $>100 \mu \mathrm{g} / \mathrm{mL}$. Thus, based on this stipulation, our finding showed that the semipolar fraction of the ethanol 


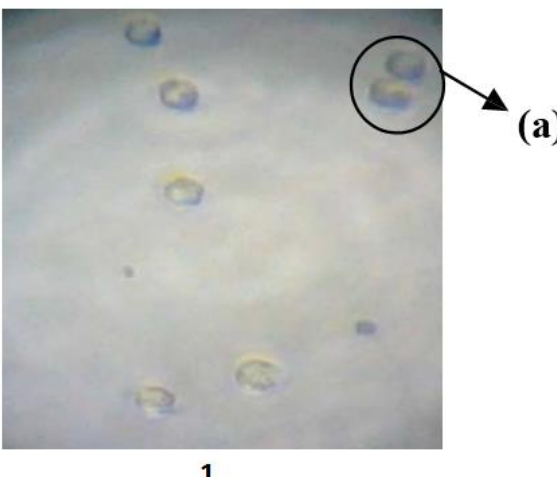

1

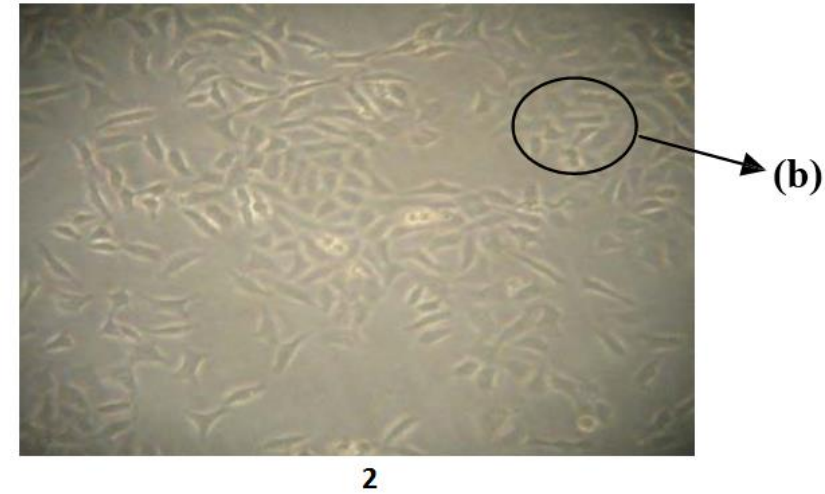

Figure 3. The treatment effect of the fraction on the morphology of T47D cells. (1) Cells were treated with $250 \mu \mathrm{g} / \mathrm{mL}$, while (2) were treated with $25 \mu \mathrm{g} / \mathrm{mL}$ of the fraction. (a) Dead cells (b) live cells

extract from sugar apple's stem bark have relatively fair cytotoxicity against T47D cells.

This $\mathrm{IC}_{50}$ value was then compared with another fractions, which are the nonpolar and polar fractions. The semipolar fraction of the ethanol extract from sugar apple's stem bark has higher cytotoxicity than the nonpolar and the polar fractions with the $\mathrm{IC}_{50}$ value of 237.317 (Rahayu, 2012) and $74.665 \mu \mathrm{g} / \mathrm{mL}$ (Rachmayanti, 2012) respectively. However, the semipolar fraction was less effective in inhibiting the growth of T47D cells compared with the ethanol extract from sugar apple's stem bark itself with the $\mathrm{IC}_{50}$ value of 43.93 $\mu \mathrm{g} / \mathrm{mL}$ (Umma, 2012). Similar cytotoxicity experiments were done using the leaves and seeds of sugar apple on T47D cells. The polar fractions of ethanol extract from sugar apple's leaves and seeds had the IC50 values of 110.30 and $23.34 \mu \mathrm{g} / \mathrm{mL}$ respectively (Meiningrum, 2012; Rimbawan, 2012). Therefore, this data is in line with the previous findings indicating that the seeds of sugar apple has the most satisfying cytotoxic activity on cancerous cells (Pisutthanan et al. 2004; Pardhasaradhi et al., 2005).

In this experiment, DMSO was used as a solvent to dilute the samples. The highest concentration of the fraction during MTT assay was $250 \mu \mathrm{g} / \mathrm{mL}$ with $0.5 \%$ of DMSO. According to the previous finding, DMSO with the concentrations of $0,5 \%$ should not interfere with the cells viability (Chen and Thibeault, 2013) which also in line with our data. The morphology of T47D cells receiving the highest and lowest concentration of the fraction can be seen in Figure 3. Based on the results, it can be concluded that the semipolar fraction of the ethanol extract from sugar apple stem bark has potential cytotoxic activity against T47D cellsQualitative analysis of secondary metabolites content of the semipolar fraction of the ethanol extract from sugar apple stem bark

The analysis was done using TLC method focusing on the detection of the alkaloids, polyphenols, and flavonoids content in the fraction visualized by the spray reagents of Dragendorff, $\mathrm{FeCl} 3$, and sitroboric, respectively. The result of the TLC can be seen in Figure 4. The presence of alkaloids can be detected with Dragendorff reagent as a brown-red fluorescence under UV light of $366 \mathrm{~nm}$ (Wagner et al, 1995). The alkaloids group in the semipolar fraction was found to be on RF of 0,53 (Figure 4, picture 2).

Next, we also attempted to detect the flavonoids group in the fraction. Flavonoids would react with boric acid and citric acid in the sitroboric reagent forming bonds that will be seen as yellow-greenish fluorescence under UV light of $366 \mathrm{~nm}$ (Markham, 1982). Our samples showed two positive results with 


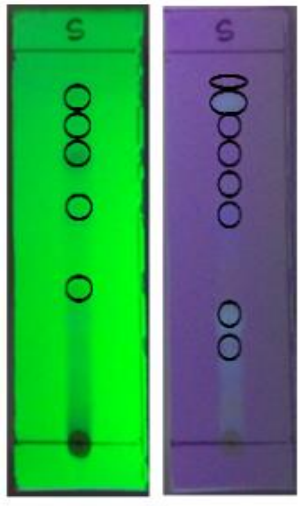

1

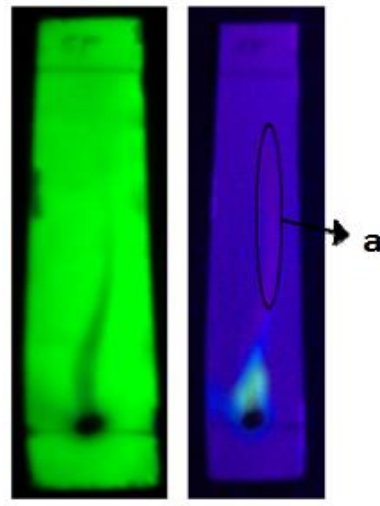

2

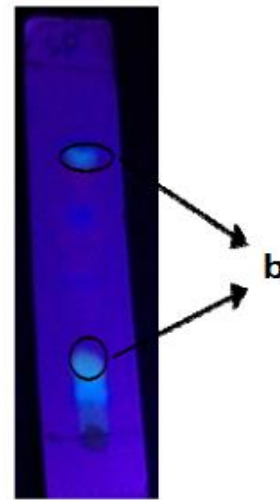

3

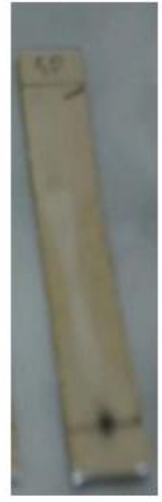

4

Figure 4. Detection of alkaloids, flavonoids, and polyphenols content using normal phase TLC method with hexane:ethyl acetate $(7: 3)$.

(1) The spots visualized under UV $254 \mathrm{~nm}$ (left) and $366 \mathrm{~nm}$ (right). (2) The plate was sprayed with Dragendorff reagent for alkaloids detection then observed under UV $254 \mathrm{~nm}$ (left) and $366 \mathrm{~nm}$ (right). (a) alkaloids were indicated with brownish red fluorescence under UV $366 \mathrm{~nm}$. (3) The plate was sprayed with sitroboric reagent for flavonoids detection and observed under UV $366 \mathrm{~nm}$, (b) yellow greenish

fluorescence indicated the presence of flavonoids. (4) The plate was sprayed with $\mathrm{FeCl} 3$ reagent for polyphenols detection and then observed under visible light. Dark blue-grey spots indicating polyphenols content in the fraction.

Table 2. TLC result of the secondary metabolites content of the semipolar fraction of ethanol extract from sugar apple stem bark

\begin{tabular}{lccc}
\hline Detection & Rf & $\begin{array}{c}\text { Secondary metabolite } \\
\text { groups }\end{array}$ & Results \\
\hline UV 254 nm & $0.37 ; 0.59 ; 0.74 ; 0.81 ;$ and 0.89 & - & Five spots detected \\
UV 366 nm & $0.21 ; 0.32 ; 0.56 ; 0.67 ; 0.70 ; 0.74 ;$ & - & Eight spots detected \\
Dragendorff & $0.88 ;$ and 0.92. & Alkaloid & Positive \\
Sitroboric & 0.53 & Flavonoid & Positive \\
$\mathrm{FeCl}_{3}$ & 0.19 and 0.76 & Tannins and Polyphenols & Negative \\
\hline
\end{tabular}

this test on RF of 0.19 and 0.76 after heating the plate on $105^{\circ} \mathrm{C}$ for five minutes (Figure 4, picture number 3). Last, polyphenols content was identified using $\mathrm{FeCl}_{3}$ reagent. $\mathrm{FeCl}_{3}$ reagent can be to detect polyphenols and tannins where positive are indicated by grey, dark green to bluish spots under the visible light as the result of the reaction between the $\mathrm{Fe}^{3+}$ and the hydroxyl groups. Interestingly, even though polyphenols are abundant in plants but we could not find the dark spots throughout the elution area indicating the negative result. However, there was blackgreyish spot at the start line, the lower part of the plate (Figure 4, number 4). Therefore, we assume that our mobile phase was not able to separate the sample. This may happen since the solvent used was relatively less polar than the polyphenols, so the polyphenols group would have stronger bond with the stationary phase, and thus would be retained at the lower part of the plate. Based on that assumption, this result is possibly false negative, further improvement of the system is needed in order to successfully identify the polyphenols group. The complete result from the TLC step can be referred in Table 2. 


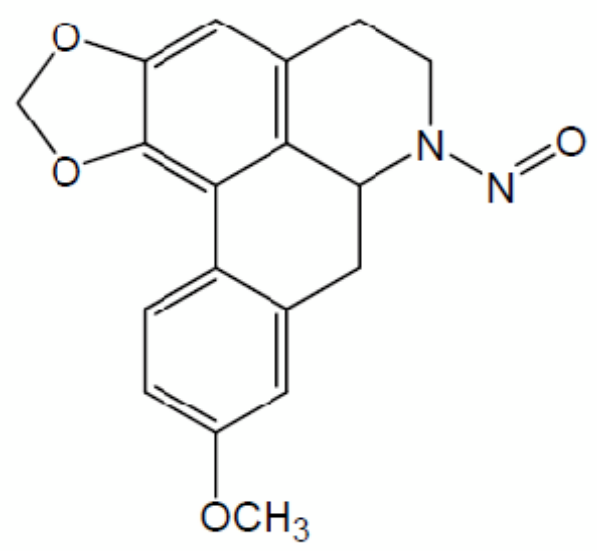

Figure 5. N-nitrosoxylopine compound found in the ethanol extract of sugar apple stem bark

Based on the previous research, the compounds responsible for the cytotoxic activity of sugar apple stem bark was acetogenins (Villo, 2008). Acetogenins are potential anticancer agents isolated from Annonaceae family, including sugar apple (Annona squamosa L). Acetogenin is an amphiphilic molecule consists of polar group binds with two lipophilic chains connected with the lactone ring (Villo, 2008), which makes acetogenins are highly possible to be extracted with semipolar solvent, especially in this experiment. Unfortunately, this research was not able to confirm the presence of acetogenins in the fraction, thus, the compounds responsible for the cytotoxic activity is still unidentifiable.

Alkaloids have been widely investigated as one of potential agents that possess significant cytotoxic activity and have been used in a cancer therapy (Mondal et al., 2019). Alkaloids in Catharantus roseus were shown to have the ability to inhibit metaphase step in the leukemic P-1534 cell cycle in rats leading them to death (Pardhasaradhi, 2004). Another research proved that the alkaloids isolated from Cananga odorata, sampangine, were able to increase the formation of ROS (Reactive Oxygen Species) inside the cells, thus inducing their apoptosis (Wink, 2007). One of the alkaloids contained in the sugar apple stem bark called annonaine, was claimed to have various pharmacological activities (Pandey et al., 2011). In addition, Johns et al., (2011) isolated three aporphine alkaloids of the ethanol extract from sugar apple stem bark which showed effective antimalarial activity. Between these three alkaloids, there was one compound namely $\mathrm{N}$ Nitrosoxylopine (Figure 5) which possessed cytotoxicity against $\mathrm{CHO}$ (Chinese Hamster Ovarian) cells. The mechanism of its cytotoxic activity was not clearly elucidated; however, it was reported that the nitroso group was possibly account for the activity (Figure 5). Therefore, to conclude, the semipolar fraction of the ethanol extract from sugar apple stem bark has potential cytotoxicity against T47D cells and based on the literature, it is likely that the alkaloids contained in the fraction played role in its cytotoxic activity. Considering its potential as the new option for cancer therapy, it is necessary to further isolate the major compound responsible for its cytotoxic activity and to elucidate the mechanism of action in its cytotoxicity of this fraction.

\section{CONCLUSION}

This research proved that the semipolar fraction of the ethanol extract from sugar apple stem bark is toxic towards T47D cells with the IC50 value of $70.77 \mu \mathrm{g} / \mathrm{mL}$. On top of that, this fraction was indicated to have 
alkaloids and flavonoids content which is possibly to be responsible for its pharmacological activity, including its cytotoxicity.

\section{References}

Chen, X. and Thibeault, S. (2013) 'Effect of DMSO concentration, cell density and needle gauge on the viability of cryopreserved cells in three dimensional hyaluronan hydrogel', in Proceedings of the Annual International Conference of the IEEE Engineering in Medicine and Biology Society, EMBS. NIH Public Access, pp. 6228-6231. doi: 10.1109/EMBC.2013.6610976.

Johns, T., Windust, A., Jurgens, T., \& Mansor, S.M., 2011, Antimalarial alkaloids isolated from Annona squamosa, Phytopharmacology, 1(3) 49-53.

Karimi, A., Majlesi, M. and Rafieian-Kopaei, M. (2015) 'Herbal versus synthetic drugs; beliefs and facts.', Journal of nephropharmacology. Society of Diabetic Nephropathy Prevention, 4(1), pp. 27-30. Available at: http://www.ncbi.nlm.nih.gov/pubmed/28197471 (Accessed: 28 December 2020).

Kementrian Kesehatan RI (2018) 'Pedoman Nasional Pelayanan Kedokteran Tata Laksana Kanker Payudara', Keputusan Menteri Kesehatan Republik Indonesia, 2, pp. 227-249.

Kementrian Kesehatan RI (2019) Hari Kanker Sedunia 2019, https://www.kemkes.go.id/. Available at: https://www.kemkes.go.id/article/view/19020100003/hari-kanker-sedunia2019.html (Accessed: 28 December 2020).

Markham, K.R., 1982, Cara Mengidentifikasi Flavonoid, diterjemahkan oleh Kosasih Padmawinata, Penerbit ITB, Bandung.

Meiningrum, I., 2012, Aktivitas Sitotoksik Fraksi Polar Ekstrak Etanol Daun Srikaya (Annona squamosa L.) Terhadap Sel T47D, Skripsi, Fakultas Farmasi Universitas Muhammadyah Surakarta, Surakarta.

Mondal, A. et al. (2019) 'Alkaloids for cancer prevention and therapy: Current progress and future perspectives', European Journal of Pharmacology. Elsevier B.V. doi: 10.1016/j.ejphar.2019.172472.

Sullivan, R. et al. (2015) 'Global cancer surgery: Delivering safe, affordable, and timely cancer surgery', The Lancet Oncology, 16(11), pp. 1193-1224. doi: 10.1016/S14702045(15)00223-5.

Pandey, Neha., \& Dushyant Barve, 2011, Phytochemical and Pharmacologycal Review on Annona squamosa Linn, International Journal of Research in Pharmaceutical and Biomedical Sciences. Vol. 2(4), 1404-1412.

Pardhasaradhi, B V V., Madhurima, Reddy., Ali, A Mubarak., Kumari, A Leela., \& Khar, Ashok., 2004, Antitumour activity of Annona squamosa seed extracts is through the generation of free radicals and induction of apoptosis, Indian Journal of Biochemistry \& Biophysics, Vol. 41, 167-172.

Pardhasaradhi, B V V., Madhurima, Reddy., Ali, A Mubarak., Kumari, A Leela., \& Khar, Ashok, 2005, Differential cytotoxic effects of Annona squamosa seed extracts on human 
tumour cell lines: Role of reactive oxygen species and glutathione, J. Biosci, 30 (2), 237 244.

Pisutthanan, S., Plianbangchang, P., Pisutthanan, N., Ruanruay, S., \& Muanrit, O., 2004, Brine Shrimp Lethality Activity of Thai Medicinal Plants in the Family Meliaceae, Naresuan University Journal 2004, 12(2), 13-18.

Rajabalian, S., Foroumadi, A., Shafiee, A., \& Emami, S., 2007, Functionalized N-(2oxyminoethyl) Piperazinyl Quinolones as New Cytotoxic Agents, J Pharm Pharmaceut Sci, 10 (2), 153-158.

Rachmayanti, H., 2012, Aktivitas Sitotoksik Fraksi Nonpolar Ekstrak Etanol Kulit Batang Srikaya (Annona squamosa L.) Terhadap Sel T47D, Skripsi, Fakultas Farmasi Universitas Muhammadyah Surakarta, Surakarta.

Rahayu, W.Y., 2012, Aktivitas Sitotoksik Ekstrak Etanol Kulit Batang Srikaya (Annona squamosa L.) Terhadap Sel T47D, Skripsi, Fakultas Farmasi Universitas Muhammadyah Surakarta, Surakarta.

Rimbawan, Y., 2012, Aktivitas Sitotoksik Fraksi Polar Ekstrak Etanol Biji Srikaya (Annona squamosa L.) Terhadap Sel T47D, Skripsi, Fakultas Farmasi Universitas Muhammadyah Surakarta, Surakarta.

Umma, C., 2012, Aktivitas Sitotoksik Fraksi Polar Ekstrak Etanol Kulit Batang Srikaya (Annona squamosa L.) Terhadap Sel T47D, Skripsi, Fakultas Farmasi Universitas Muhammadyah Surakarta, Surakarta.

Villo, P., 2008, Synthesis of Acetogenins Analogues, Tesis, Intitute of Technology Faculty of Science and Technology, University of Tartu.

Wagner, H., Bladt, S., \& Zgainski, E. M., 1995, Plant Drug Analisys: A Thin Layer Chromatography Atlas, diterjemahkan oleh Th. A. Scott, Springer-Verlag, Berlin.

Wang, D.-S. et al. (2014) Annona squamosa Linn: cytotoxic activity found in leaf extract against human tumor cell lines - PubMed, Pak J Pharm Sci. 2014 Sep;27(5 Spec no):155963. doi: 25176251.

Wink, M., 2007, Molecular Modes of Action of Cytotoxic Alkaloids: From DNA Intercalation, Spindle Poisoning, Topoisomerase Inhibition to Apoptosis and Multiple Drug Resistance, The Alkaloids, Volume 64, 1-47. 